\title{
A Pluralistic Approach towards Sustainable Eco-Industrial Networking
}

\author{
Ovidiu Noran*, David Romero** \\ *Griffith University, Australia,o.noran@griffith.edu.au \\ **Tecnológico de Monterrey, Mexico,david.romero.diaz@gmail.com
}

\begin{abstract}
Corporate environmental responsibility is rapidly evolving into a crucial aspect of strategic management as worldwide recycling and emission regulations are tightening in order to mitigate the effects of waste and greenhouse effects towards climate change and natural disasters. Enterprises typically respond to this challenge by implementing environmental reporting and management systems. However, their environmental programs are often not properly integrated in the overall business strategy. Moreover, within Collaborative Networks (CNs), the Environmental Management (EM) effort is often not optimally coordinated amid partners in order to achieve a much needed synergy. Eco-Industrial Networking (EIN) is increasingly becoming an important $\mathrm{CN}$ strategy towards a systems-based approach for improving EM and competitiveness in the industrial landscape. EIN aims to maximise eco-efficiency and minimise environmental impact in value chains and networks; currently however, the effort towards a sustainable and efficient EIN is still in an infancy stage. This paper proposes a way forward in tackling the EIN challenge by means of a multidisciplinary approach grounded in the wealth of knowledge accumulated in the Collaborative Networks, Industrial Ecology, Systems Engineering and Enterprise Architecture research disciplines. This pluralistic viewpoint is expected to provide a sound holistic and lifecycle based approach towards the sustainable eco-industrial initiative.
\end{abstract}

Keywords: Industrial Ecology, Collaborative Networks, Enterprise Architecture, Systems Theory, Systems Engineering, System of Systems, Eco-industrial Networking

\section{INTRODUCTION}

The continued existence of businesses depends on their economic sustainability but also on their impact on the natural environment and on the way they treat their workers. This fact was emphasised by Elkington's 'Triple Bottom Line' approach (1998) to business sustainability: one must achieve economic bottom-line performance but also environmental and social goals. In Blackburn's (2007) metaphor, economic sustainability is air, while environmental and social sustainability are food: the first is more urgent however not more important than the second. Successful sustainable organisations have to also observe the '2Rs' (Respect for humans and judicious Resource management) and thus take a whole-system approach to sustainable development (UN WCED, 1987). Enterprises can also increase competitiveness and become more profitable by leveraging customers' environmental concern and preference for 'green' products (Sarkis, 2003).

These principles are carried on in the Collaborative Networks (CNs) that companies often form in order to increase efficiency, gain critical mass and allow them to promptly create Virtual Enterprises (VEs) able to bid for projects that go beyond the individual competencies of the $\mathrm{CN}$ participants (Camarinha-Matos et al., 2009). Thus, for example, 'green' supply chains are aimed at the optimising the use of energy, and materials, minimise the emissions and waste in production and logistics processes and promoting the usage of recyclable materials and renewable energy sources. This is achieved by employing reverse, or closed-loop logistics and integrating forward and reverse supply chains (Meade et al., 2007; Srivastava, 2007; Romero \& Molina, 2013).

Previous research has proposed methods to better integrate and coordinate Environmental Management programs amid the CNs and VE partners (Noran, 2009, 2010) while also defining specific features of 'green' CNs representing sustainable industrial development models (Romero \& Molina, 2011, 2012). This paper aims to take this research further by employing a pluralistic approach involving the use of Systems Theory (ST), Systems Engineering (SE) and System of Systems (SoS) using an Enterprise Architecture (EA)-based framework to evolve sustainable-conscious CNs into symbiotic Eco-Industrial Networks (EINs) featuring closed-loop systems of materials, water, energy, waste, byproducts, and information ( see Fig. 1).

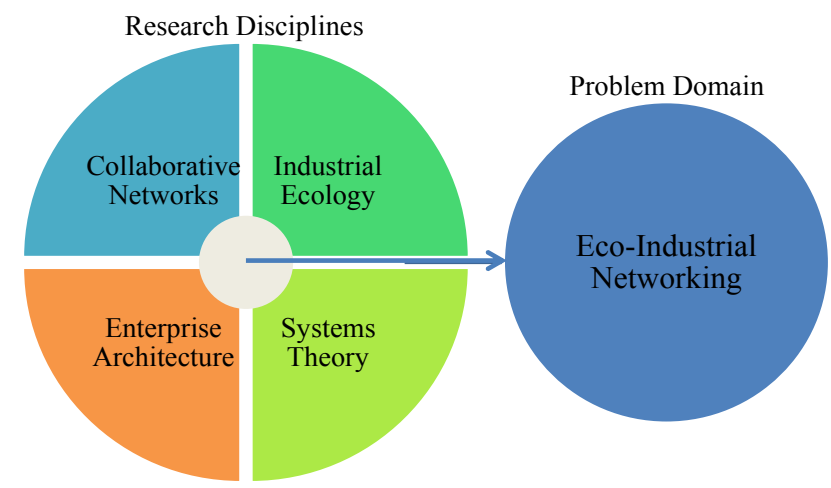

Fig. 1. A Pluralistic Approach to Eco-Industrial Networking 


\section{INDUSTRIAL ECOLOGY CONTRIBUTIONS}

Today's industrial practices require new and sustainable industrial development models. Manufacturers and service providers require new operational models to respond to a growing market segment of green consumers and government authorities encompassing new 'green' legislations and law enforcement for environmental protection. As a result, new action frameworks are needed to eco-restructure the industrial landscape (Romero \& Molina, 2011).

Industrial Ecology (IE) represents a systems-based, multidisciplinary discourse with contributions from economic, social, environmental and technological sciences. IE seeks to provide new environmental management practices based on industrial systems that operate according to natural ecosystem models (Allenby, 2006). Furthermore, IE aims to support the holistic implementation of sustainable industrial development by offering specific practices to optimise the use of resources, close material loops, minimise emissions, dematerialise activities and reduce or even eliminate the dependence on non-renewable sources of energy (International Society for Industrial Ecology (IS4IE), 2013).

IE embodies the paradigm shift from a linear industrial model where resources move through the system to become waste, to a new integrated and cyclic industrial eco-system optimising systematically all kind of resources flows (e.g. materials, water, energy, waste, by-products, information, etc.) to up-cycle and down-cycle them as inputs for new processes, so under-utilisation of resources can be avoided and therefore reduce the dependency on non-renewable natural resources (ibid.).

Industrial eco-systems (also known as 'industrial symbiosis clusters' (Chertow, 2000)) are in fact complex systems featuring a large number and variety of autonomous and geographically distributed entities that possess combinations of interrelated, interdependent and/or interactive components within their 'techno-sphere' (man-made technological systems such as: factories at micro-level, industrial value chains and networks at meso-level and industry clusters at macro-level) and their 'biosphere' (natural ecosystems) (Romero \& Molina, 2012).

While both natural and industrial symbiosis are complex systems, industrial symbiosis needs to be designed and managed by people, who need to employ a systematic approach in order to better understand the full design and managerial implications of their decisions in the process of creating true industrial eco-systems (Sopha et al., 2010).

When developing industrial eco-systems from an industrial symbiosis perspective, Heers et al. (2004) and Mirata (2005) propose: 1) a technical domain, in terms of technically feasible exchanges of in- and out-streams; 2) an economic domain, related to economically sound exchanges; 3) a political/regulatory/legal domain caused by environmental laws and regulations; 4) an informational domain promoted by the need of data and information for better decisionmaking and collaborative process orchestration; and 5) an organisational/institutional domain to deal with various collaborative and environmental corporate maturity levels.

\section{COLLABORATIVE NETWORKS CONTRIBUTIONS}

In today's competitive and global commercial environment, companies often need to use various forms of cooperation that enables them to tackle complex tasks together. One of such cooperation forms are $\mathrm{CNs}$, which allow network members to promptly create VEs able to bid for projects that go beyond the individual competencies of any $\mathrm{CN}$ participant. Similarly, achieving a truly sustainable industry is only possible through wide collaboration among a multitude of stakeholders as the magnitude of changes required exceeds the capability of any individual enterprise. Therefore, the concepts, methods and tools developed in the $\mathrm{CN}$ discipline can facilitate the engagement and interplay of the stakeholders involved in any sustainability effort. $\mathrm{CN}$ also offers synergy potential with other sustainability fields such as the IE discipline (Romero \& Molina, 2010).

More specifically, the $\mathrm{CN}$ body of knowledge can contribute several other domains deemed of relevance when designing and managing industrial eco-systems, such as 6) a target(s) domain aimed to guide any action by common or compatible goals setting; 7) an actors' domain associated with the roles, rights and responsibilities associated to each member organisation; 8) an operating principles domain establishing common guidelines to permit collaborative work to be conducted; 9) a lifecycle domain coping with the life span of any collaboration opportunity; and 10) a supporting technologies domain related to all tools, methods, mechanisms, systems and processes allowing member organisations to interoperate and cooperate for different collaborative purposes (Romero \& Molina, 2011).

\section{SYSTEMS THEORY, SYSTEMS ENGINERING AND SYSTEM OF SYSTEMS CONTRIBUTIONS}

Although currently there is no unanimously accepted definition of 'System of Systems' (SoS), a common approach (also used in this study) considers SoS to be 'meta-systems' that are in turn composed of several other independent embedded complex systems varying in "technology, context, operation and conceptual frame" (Keating et al., 2003). In other words, SoS is a collection of systems that contribute their resources and capabilities to create a more complex system, which displays more functionality and performance compared to the simple total of the constituent systems.

Although still in full development, the SoS research can provide valuable viewpoints and methodologies towards EIN. For example, Maier (1998) describes several features of SoS that can be applied to EIN: operational and managerial independence, geographic distribution, evolutionary behaviour and emergent behaviour. DeLaurentis and Ayyalasomayajula (2009) describe further potential SoS contributions to EIN; thus, due to its trans-domain, multiperspective and component quasi-independence features, the SoS paradigm can help ascertain the level of scalability of Eco-Industrial networks, analyse the effects of network participant actions as agents on the network as a whole and mitigate conflicting stakeholder objectives.

A major challenge in sustainable development is to address environmental protection, economic growth and social 
progress in a cohesive and holistic way (Dassisti et al., 2013). Thus, sustainability can be tackled as a 'system of systems' providing an integrated view and approach towards the sustainable industrial development challenge. Along these lines, Systems Theory (ST) can be used to define what an industrial eco-system should be and how it should function and to give a better understanding of the roles and relationships between the various stakeholders. Thus, ST can provide a conceptual framework for outlining an industrial eco-system (Sopha et al., 2010).

Systems Engineering (SE) can also be employed in this context to contribute to a toolbox for managing the design of industrial eco-systems. SE efforts are mainly concerned with the appropriate detail definition, development and deployment of a system, ensuring that the industrial ecosystem is correctly modelled (ibid.).

\section{ENTERPRISE ARCHITECTURE CONTRIBUTION}

EIN requirements, design, behaviour and performance are inherently linked to the current lifecycle phase(s) of the host organisations; it is therefore essential that the analysis of EIN creation and operation is performed in a lifecycle context. It is hereby argued that an optimal way to integrate the lifecycle and other essential aspects in a sustainable EIN scenario is by involving the Enterprise Architecture (EA) body of knowledge.

Similar to SoS, EA is a research discipline whose definition and glossary are in full evolution. For the purpose of this work, we adopt the state-of-the-art concept of EA seen as a holistic change management paradigm that bridges management and engineering best-practice, providing the "[...] key requirements, principles and models that describe the enterprise's future state. [...]. Thus, EA comprises people, processes, information and technology of the enterprise, and their relationships to one another and to the external environment" (Gartner Research, 2012). This EA definition reinforces the view of $\mathrm{CNs}$ as social systems composed of commitments (Neumann et al., 2011) and socio-technical systems (Pava, 1983) with voluntaristic people (McGregor, 1960) in a complex organisational, political and behavioural context (Iivari, 1991; Markus, 1983).

Thus, EA is capable of providing a framework integrating all necessary aspects in a lifecycle-based set of models ensuring the consistency and sustainability of complex projects, of which EIN is a prime example. The EA principles and artefacts can be effectively applied within the network members but also scaled up to the network as a whole in order to model the complex interactions that take place, in an integrated approach containing the viewpoints deemed of interest to the EIN task at hand. EA can thus model the creation and operation of an EIN, potential VEs produced by it and projects managed by these VEs. This type of modelling has been tested in previous research in disaster, health and environmental management, as well as sustainability and standardisation (Noran, 2010, 2012; Noran \& Bernus, 2011; Noran \& Panetto, 2013), manufacturing (Mo, 2007), mergers and acquisitions (Nemes \& Mo, 2010) to mention just a few.

\section{A PLURALISTIC VIEW ON ECO-INDUSTRIAL NETWORKING SETUP AND OPERATION}

No enterprise or network can be considered separate from the complex environment they operate in. Therefore, Table 1 details, in a lifecycle context provided by an EA modelling framework (GERA, in (ISO/IEC, 2005)) the potential areas of contribution of the various research disciplines to EIN (enablers) but also specifies the influence of external factors on the proposed network (drivers).

The Identification phase may be the most important for the agile business. Thus, anticipation or early recognition of future legislation, support and market trends and their popularity among the public and various organisations holds the key towards achieving or keeping a competitive edge. In the current context of consumers, society, non-governmental organisations (NGOs) and government pressures prompting enterprises to reduce their environmental footprint, decisive action is required to improve environmental performance.

In the next phase, Concept, it must be realised that any effective environmental improvement effort cannot be isolated to any one enterprise. Thus, companies should look into potential industrial symbiosis opportunities to close-loop their industrial linear chains by collaborating with each other to maximise resources use and minimise waste by converting their by-products into inputs for processes of other enterprises (Heeres et al., 2004) and by sharing resources when possible to avoid redundant assets; effectively, this brings about the concept of an industrial eco-system. This is the point where potential challenges and required readiness for the envisaged EIN are to be conceptually defined. For example: what is the interoperability level desired? Should it be full integration, federalisation, or unified (cf. ISO14258 (2005))? What about the effects on resilience and agility? What are the challenges and barriers to achieving the desired EIN type?

Previous industry experience shows that the development of the EIN concept is best divided only along network management and operation lines with other aspects deferred to the next phase. Similarly, the tools and models used in Identification and Concept phases should be minimalistic: as shown in previous case studies (Noran, 2009, 2010), in early project life cycle phases, stakeholder synergy and consensus may be stifled by complex languages and supporting tools.

Next, the efforts should focus on defining the functional / technical, economic, political, informational, and organisational Requirements for designing, implementing and operating a collaborative closed-loop environment. This requirements list will also form the basis for the initial and on-going search and selection of the most suitable partners (e.g. whose processes present the highest readiness level to become interoperable). Furthermore, requirements gathering will help assess the interoperability maturity level of each potential collaborative partner as well as its economic performance in order to achieve an eco-efficient network.

An important phase in the EIN development is Architectural design, where an implementation-independent solution fulfilling the identified requirements is to be developed. 
Table 1. Potential Drivers and Enablers in the Setup and Operation of an Eco-Industrial Network

\begin{tabular}{|c|c|c|c|c|c|c|c|c|}
\hline & \multicolumn{4}{|c|}{ External Factors (Drivers) } & \multicolumn{4}{|c|}{ Internal Factors (Enablers) } \\
\hline & Market & Support & Society & Legislation & $I E$ & $C N$ & $S T\|S E\| S o S$ & $E A$ \\
\hline Identification & $\begin{array}{c}\text { Green } \\
\text { Consumers }\end{array}$ & $\begin{array}{l}\text { Non- } \\
\text { Governmental } \\
\text { Environmental } \\
\text { Organisations }\end{array}$ & $\begin{array}{c}\text { Total Available } \\
\text { Green Markets } \\
\text { (Environmental } \\
\text { Awareness) }\end{array}$ & \multirow{2}{*}{$\begin{array}{c}\text { Governmental } \\
\text { Environmental } \\
\text { Pressures }\end{array}$} & $\begin{array}{l}\text { Discovering } \\
\text { Industrial } \\
\text { Symbiosis } \\
\text { Opportunities }\end{array}$ & $\begin{array}{l}\text { Collaboration } \\
\text { Opportunities } \\
\text { Identification }\end{array}$ & $\begin{array}{l}\text { Integration and } \\
\text { Interoperability } \\
\text { Opportunities }\end{array}$ & $\begin{array}{c}\text { Discover } \\
\text { Sustainability } \\
\text { \& Consequent } \\
\text { Challenges }\end{array}$ \\
\hline Conceptualisation & $\begin{array}{c}\text { New } \\
\text { Green } \\
\text { Customer } \\
\text { Profile } \\
\end{array}$ & $\begin{array}{c}\text { New } \\
\text { Support } \\
\text { Institutions }\end{array}$ & $\begin{array}{c}\text { Serviceable } \\
\text { Addressable } \\
\text { Market }\end{array}$ & & $\begin{array}{c}\text { Closed-Loop } \\
\text { Systems Models }\end{array}$ & $\begin{array}{l}\text { Collaboration } \\
\text { Opportunities } \\
\text { Characterisation }\end{array}$ & $\begin{array}{c}\text { Integration and } \\
\text { Interoperability } \\
\text { Challenges and } \\
\text { Readiness } \\
\end{array}$ & $\begin{array}{c}\text { EIN } \\
\text { Management } \\
\text { and Product } \\
\text { Concepts } \\
\end{array}$ \\
\hline Requirements & \multirow{3}{*}{$\begin{array}{l}\text { New } \\
\text { Green Value } \\
\text { Propositions } \\
\text { (Goods and } \\
\text { Services) }\end{array}$} & \multirow{3}{*}{$\begin{array}{c}\text { New } \\
\text { Green } \\
\text { Partnerships }\end{array}$} & $\begin{array}{c}\text { Target } \\
\text { Green Markets }\end{array}$ & $\begin{array}{c}\text { Environmental } \\
\text { Laws } \\
\& \\
\text { Regulations }\end{array}$ & $\begin{array}{c}\text { Technical, } \\
\text { Economic, } \\
\text { Political, } \\
\text { Information, } \\
\text { Organisational } \\
\text { Requirements } \\
\end{array}$ & $\begin{array}{c}\text { CN Partners } \\
\text { Selection Criteria } \\
\text { based on } \\
\text { Competency } \\
\text { Assessment }\end{array}$ & $\begin{array}{l}\text { Integration and } \\
\text { Interoperability } \\
\text { Requirements to } \\
\text { meet challenges }\end{array}$ & $\begin{array}{l}\text { EIN Policies } \\
\text { Functional, } \\
\text { Information, } \\
\text { Resources, } \\
\text { Organisation } \\
\text { (FIRO) } \\
\end{array}$ \\
\hline $\begin{array}{c}\text { Architectural } \\
\text { Design }\end{array}$ & & & $\begin{array}{c}\text { Segment } \\
\text { Green Markets }\end{array}$ & \multirow{2}{*}{$\begin{array}{c}\text { Green } \\
\text { Standards } \\
\text { e.g. } \\
\text { ISO14001 } \\
(2004)\end{array}$} & $\begin{array}{c}\text { Industrial } \\
\text { Eco-Systems } \\
\text { Typology }\end{array}$ & $\begin{array}{c}\text { CN Rough } \\
\text { Planning } \\
\text { (Topology, } \\
\text { Activities, Tasks, } \\
\text { Budget, KPIs, } \\
\text { Risk) }\end{array}$ & $\begin{array}{l}\text { Integration and } \\
\text { Interoperability } \\
\text { Approaches }\end{array}$ & $\begin{array}{l}\text { FIRO, Mgmt. } \\
\text { vs. product, } \\
\text { Human AS-IS } \\
\text { and TO-BE } \\
\text { modelling }\end{array}$ \\
\hline Detailed Design & & & $\begin{array}{l}\text { Green Markets } \\
\text { Entry Strategy } \\
\text { Planning }\end{array}$ & & $\begin{array}{c}\text { Industrial } \\
\text { Eco-System } \\
\text { Technical Model }\end{array}$ & $\begin{array}{c}\text { CN Detailed } \\
\text { Planning } \\
\text { (WBS, Gantt); CN } \\
\text { partial models }\end{array}$ & $\begin{array}{l}\text { Integration and } \\
\text { Interoperability } \\
\text { Solutions }\end{array}$ & \begin{tabular}{|c} 
FIRO, Mgmt. \\
vs. product, \\
Human SW \\
vs. HW, \\
modelling \\
\end{tabular} \\
\hline Implementation & $\begin{array}{c}\text { Green } \\
\text { Marketing }\end{array}$ & $\begin{array}{l}\text { Collaboration } \\
\text { Agreements }\end{array}$ & \multirow{2}{*}{$\begin{array}{l}\text { Green Markets } \\
\text { Entry Strategy } \\
\text { Execution }\end{array}$} & \multirow{2}{*}{$\begin{array}{c}\text { Green } \\
\text { Behaviour } \\
\text { Compliance }\end{array}$} & $\begin{array}{c}\text { Industrial } \\
\text { Eco-System } \\
\text { Business Model }\end{array}$ & $\begin{array}{c}\text { CN Launching } \\
\text { (Contracts and } \\
\text { Agreements) }\end{array}$ & $\begin{array}{l}\text { Integration and } \\
\text { Interoperability } \\
\text { Implementation } \\
\text { Projects }\end{array}$ & $\begin{array}{c}\text { Customised } \\
\text { Transition } \\
\text { Methodologies }\end{array}$ \\
\hline Operation & $\begin{array}{l}\text { Sustainable } \\
\text { Consumption }\end{array}$ & Joint Ventures & & & $\begin{array}{l}\text { Industrial } \\
\text { Eco-System } \\
\text { Operation } \\
\text { Principles }\end{array}$ & $\begin{array}{l}\text { CN Management, } \\
\text { Coordination and } \\
\text { Supervision } \\
\text { Mechanisms }\end{array}$ & $\begin{array}{c}\text { Network } \\
\text { Evolutionary } \\
\text { and Emergent } \\
\text { Behaviour }\end{array}$ & $\begin{array}{l}\text { Continuous } \\
\text { Improvement } \\
\text { Management ; } \\
\text { Life History } \\
\text { vs. Life Cycle }\end{array}$ \\
\hline $\begin{array}{l}\text { Decommissioning } \\
\text { or Revamping }\end{array}$ & $\begin{array}{l}\text { Recycling } \\
\text { Behaviour }\end{array}$ & $\begin{array}{l}\text { Sharing } \\
\text { Experience }\end{array}$ & $\begin{array}{c}\text { Green Markets } \\
\text { Evolution }\end{array}$ & $\begin{array}{l}\text { Environmental } \\
\text { Regulations } \\
\text { Evolution }\end{array}$ & $\begin{array}{l}\text { Industrial } \\
\text { Eco-System } \\
\text { Evolution or } \\
\text { Dissolution }\end{array}$ & $\begin{array}{l}\mathrm{CN} \text { Inheritance } \\
\text { Management }\end{array}$ & & $\begin{array}{c}\text { Customised } \\
\text { Retirement / } \\
\text { Transition } \\
\text { Methodologies }\end{array}$ \\
\hline
\end{tabular}

Establishing and nurturing symbiotic collaborations will require the alignment of the EIN participants so as to meet the multitude of interoperability challenges that typically arise. For this purpose, EA-specific MFs can provide a repository of applicable viewpoints reflecting the various stakeholder concerns, e.g. as per ISO42010 (2007) and ISO15704 (2000). Thus for example, function (process), information, resources, organisation, decisional, economic and risk models may be developed, integrating knowledge from IE, CN and SoS as shown in Table 1.

Importantly, the automation boundary (tasks executed by humans vs. machine) needs to be also considered starting with this phase (see e.g. Fig 2). The architectural design phase is decisive because at its end, typically a 'go/no-go' decision is to be made in respect to the continuation of the EIN project, depending on its technical / financial etc. feasibility.

In essence, there are two main ways that potential EIN participants can go about reaching the required collaborative closed-loop preparedness required for an effective industrial eco-system.

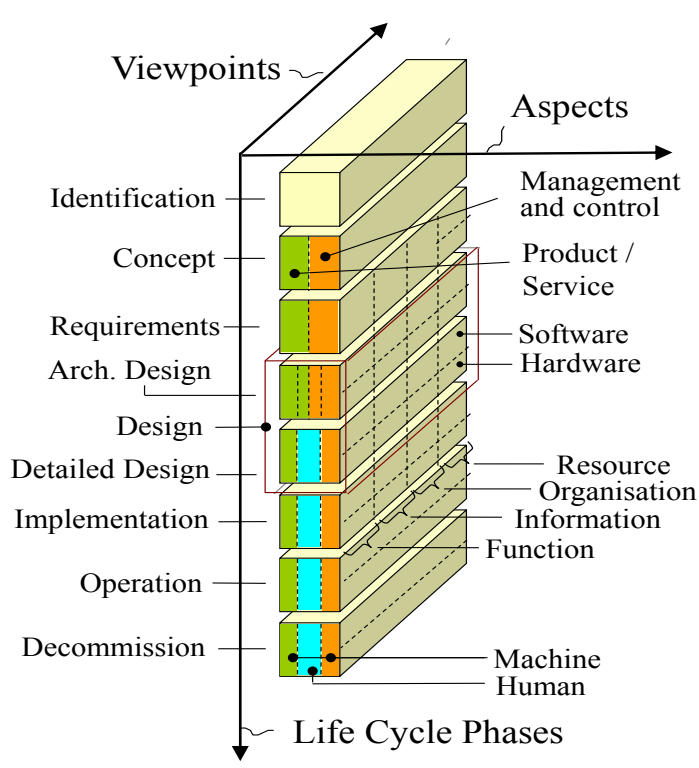

Fig. 2. Sample viewpoints and aspects provided by the modelling framework of an EA framework (ISO/IEC, 2005) 
The first approach is to 'plug' the required inputs, outputs, controls and resources into the partners' existing processes; adding the necessary management tasks and decisional frameworks on top of their existing organisational and decisional frameworks; and so on (see (Noran, 2009) for an example). The second approach involves the complete transformation of partners' every artefact involved in the future EIN participation - a potentially complex and lengthy endeavour (if more efficient in the long run). Depending on the urgency of the EIN project, extent of interoperability and thus resilience and agility desired or required, each participant may decide to adopt the first or the second approach - or start with the first and evolve into the second.

The Detailed Design phase will seek to find technologyspecific implementation alternatives for the modules defined in the architectural design. Here, IE, $\mathrm{CN}$ and SoS may contribute partial (reference) models abstracted from previous projects. The models constructed may now further distinguish between hardware and software; note however, that many aspects are in fact orthogonal (see Fig. 2); thus, one can describe the 'detailed design of the functional aspect of human software' - which would mean (explicit or tacit) knowledge owned by a human in regards to some procedure performed by a partner of an eco-industrial network.

Both for Architectural and Detailed Design phases there will be a need to model the AS-IS (present) state, so that the stakeholders get a common grasp of the current situation, and several TO-BE (future) states, in order for the stakeholders to agree on a preferred solution. The transition from AS-IS to the TO-BE must be managed in an integrated way; here, EA artefacts can provide project-specific transition plans using generic customisable methodologies or meta-methodologies. For the above tasks, there is a plethora of modelling languages and tools available for functional, process, information, organisational, decision etc. modelling. A crucial requirement however, is that the modelling languages used are underpinned by an integrated set of metamodels. This will ensure the overall consistency of the set of models. For example, adding or changing an input of an activity in a process model should be reflected in the information, resources, organisational, etc. models where the various aspects of that input must also be consistently represented.

The Implementation phase will see the creation of the EIN and the enactment of the previously created transition plan(s) for each members of the future EIN. Note that irrespective of the above-described integration approaches adopted, the transition can take a significant amount of time as typically; human-related processes such as gaining trust between future EIN partners cannot be rushed. However, a well-designed transition plan that allows for the human transformational processes to take place in due time and detail will result in a significantly more stable, efficient and thus competitive EIN.

Next, the EIN is launched into Operation. The SoS and CN areas can provide specific network supervision and behavioural models that help the EIN management predict and mitigate potential turbulence and instability within the network. This is especially true as network participants and EIN as a whole will typically undergo various continuous improvement projects while operating. Some EA frameworks may assist in this regard by providing artefacts that distinguish between repeatable life cycle phases and unique life history stages: at any given time during their life history, the EIN and/or members thereof may be going through several life cycle phases. For example, while operating, the EIN can be subject to the detailed redesign of some shared processes in order to improve their efficiency, followed by their implementation and subsequent release into operation. Such scenarios must be allowed for and carefully managed so they do not negatively affect EIN performance and stability.

Another important (although often overlooked) life cycle phase in the life history of the network is Decommissioning (or refurbishment - i.e. radical restructure, perhaps even involving the Concept phase). Irrespective of whether the EIN is dissolved or revamped, the accumulated knowledge must be properly preserved and abstracted into reference models for future use. IE and CN can help here with models of industrial eco-system evolution or dissolution and network inheritance, while EA can assist with concepts such as 'enterprise DNA' (Nemes \& Mo, 2010) and the creation of a transition plan towards network retirement or redeployment.

\section{CONCLUSIONS AND FURTHER WORK}

Worldwide, continual depletion of natural resources and increasing climatic and demographic changes are making all aspects of sustainability an urgent priority. Legacy islandand silo-type industry governance models and approaches are becoming obsolete and ineffective as eco-industrial networking becomes an essential enabler of sustainability.

In the context of a global economy based on ubiquitous computing and networking, it appears that no discipline can alone ensure a consistent and overarching approach to tackle the sustainability requirement. Therefore, this paper has proposed a pluralistic approach bringing together several disciplines that can lend valuable knowledge towards setting up and operating sustainable, collaborative eco-industrial networks. After briefly presenting the potential contribution of each research domain, the paper has attempted to expand on details and argue the benefits of the proposed combined approach in the context of the typical life cycle phases of an eco-industrial network setup and operation project.

Further work will further investigate the contributions of various disciplines to eco-industrial networking, including the possible creation of an ontology, theoretical framework and a repository of artefacts (languages, partial models, methods, tools, etc.) to be used in diverse eco-industrial networking scenarios. Case studies will also be sought in order to test and validate the proposed pluralistic approach.

\section{REFERENCES}

Allenby, B. (2006). The Ontologies of Industrial Ecology. Progress in Industrial Ecology, 3(1/2), 28-40.

Blackburn, William R. (2007). The Sustainability Handbook. Cornwall, UK: EarthScan Publishers.

Camarinha-Matos, L, Afsarmanesh, H., Galeano, N., \& Molina, A. (2009). Collaborative networked organizations - Concepts and practice in manufacturing 
enterprises. Computers and Industrial Engineering, 57(1), 46-60.

Chertow, M.R. (2000). Industrial symbiosis: Literature and taxonomy. Rev Energy Environ, 25, 313-337.

Dassisti, M., Jardim-Goncalves, R., Molina, A., Noran, O., Panetto, H., \& Zdravković, M. (2013). Sustainability and Interoperability: Two Facets of the Same Gold Medal. Lecture Notes in Computer Science, 8186, 250261

DeLaurentis, D., \& Ayyalasomayajula, S. (2009). Exploring the Synergy Between Industrial Ecology and System of Systems to Understand Complexity. Journal of Industrial Ecology, 13(2), 247-263.

Elkington, John. (1998). Cannibals with Forks: The Triple Bottom Line of $21^{\text {st }}$ Century Business.

Gartner Research. (2012). IT Glossary. 2012, from http://www.gartner.com/technology/itglossary/enterprise-architecture.jsp

Heeres, R.R., Vermeulen, R., \& De Walle, F.W. (2004). Ecoindustrial park initiatives in the USA and the Netherlands: first lessons. Journal of Cleaner Production, 12(8), 985-995.

Iivari, Juhani. (1991). A Paradigmatic Analysis of Contemporary Schools of IS Development. Eur. J. Information Systems, 1(4), 249-272.

International Society for Industrial Ecology (IS4IE). (2013). Definition of Industrial Ecology. from http://www.is4ie.org

ISO. (2004). ISO 14001:Environmental management systems - Requirements with guidance for use: International Standards Organisation.

ISO. (2005). ISO14258 Industrial Automation Systems Concepts and Rules for Enterprise Models.

ISO/IEC. (2005). Annex A: GERAM ISO/IS 15704:2000/Amd1:2005: Industrial automation systems - Requirements for enterprise-reference architectures and methodologies.

ISO/IEC. (2007). ISO/IEC 42010:2007: Recommended Practice for Architecture Description of SoftwareIntensive Systems.

ISO/TC184. (2000). ISO/IS 15704: Industrial automation systems - Requirements for enterprise-reference architectures and methodologies.

Keating, C., Rogers, R. , Unal, R., Dryer, D., Sousa-Poza, A., Safford, R., . . . Rabadi, G. (2003). System of Systems Engineering. Engineering Management Journal, 15(3), 36-45.

Maier, M.W. (1998). Architecting principles for system-ofsystems. Systems Engineering, 1(4), 267-284.

Markus, M.L. (1983). Power, politics, and MIS implementation. Comm ACM, 26, 430-444.

McGregor, D. (1960). The Human Side of Enterprise. New York: McGraw-Hill.

Meade, L. , Sarkis, J., \& Presley, A. (2007). The theory and practice of Reverse Logistics. 3(1), 56-84.

Mirata, M. (2005). Industrial Symbiosis: A tool for more sustainable regions. (Doctoral Thesis). Lund University, Lund.

Mo, J. (2007). The use of GERAM for Design of a Virtual Enterprise for a Ship Maintenance Consortium.
In P. Saha (Ed.), Handbook of Enterprise Systems Architecture in Practice (pp. 351-366). Hershey, USA: IDEA Group.

Nemes, L., \& Mo, J. (2010). Issues in using enterprise architecture for mergers and acquisitions In G. Doucet, J. Gotze, P. Saha \& S. Bernard (Eds.), Coherency Management: Architecting the Enterprise for Alignment, Agility and Assurance (pp. 235-262). Bloomington: AuthorHouse.

Neumann, D., de Santa-Eulalia, Luis Antonio, \& Zahn, Eric. (2011). Towards a Theory of Collaborative Systems. Adaptation and Value Creating Collaborative Networks - IFIP Advances in Information and Communication Technology, 362, 306-313.

Noran, O. (2009). Engineering the Sustainable Business: An Enterprise Architecture Approach. In G. Doucet, J. Gotze \& P. Saha (Eds.), Coherency Management: Architecting the Enterprise for Alignment, Agility, and Assurance (pp. 179-210): International Enterprise Architecture Institute.

Noran, O. (2010). Towards an Environmental Management Approach for Collaborative Networks. IFIP AICT, 336, pp. $17-24$.

Noran, O. (2012). Achieving a Sustainable Interoperability of Standards. Annual Reviews in Control, 36(2).

Noran, O., \& Bernus, P. (2011). Effective Disaster Management: An Interoperability Perspective. Lecture Notes in Computer Science, 7046, 112-121.

Noran, O., \& Panetto, H. (2013). Modelling a Sustainable Cooperative Healthcare: An Interoperability-driven Approach Lecture Notes in Computer Science, 8186, 238-249.

Pava, C. (1983). Managing New Office Technology, An Organisational Strategy. New York: Free Press.

Romero, D., \& Molina, A. (2010). Green Virtual Enterprises and their Breeding Environments. IFIP AICT, 336, pp. 25-35.

Romero, D., \& Molina, A. (2011). Green Virtual Enterprise Breeding Environment Reference Framework. IFIP AICT, 362, pp. 545-555.

Romero, D., \& Molina, A. (2012). Green Virtual Enterprise Breeding Environments: A Sustainable Industrial Development Model for a Circular Economy. IFIP AICT, 380, pp. 427-436.

Romero, D., \& Molina, A. (2013). Reverse - Green Virtual Enterprise and their Breeding Environments: ClosedLoop Networks. IFIP AICT, 408, pp. 589-598.

Sarkis, J. (2003). A strategic decision framework for green supply chain management. Journal of Cleaner Production, 11(4), 397-409.

Sopha, B.M., Fet, A.M., Keitsch, M.M, \& Haskins, C. (2010). Using Systems Engineering to Create a Framework for Evaluating Industrial Symbiosis Options. Systems Engineering, 13(2), 149-160.

Srivastava, S. K. (2007). Green supply-chain management: A state-of-the-art literature review. International Journal of Management Reviews, 9(1), 53-80.

UN WCED. (1987). UN World Commission on Environment and Development - Our Common Future (Brundtland Report). Oxford: Oxford University Press. 